AAS WORKING PAPERS IN SOCIAL ANTHROPOLOGY

Volume 6

Shalini Randeria and Ciara Grunder

\title{
THE (UN)MAKING OF POLICY IN
} THE SHADOW OF THE WORLD

BANK:

Infrastructure development, urban resettlement and the cunning state in India

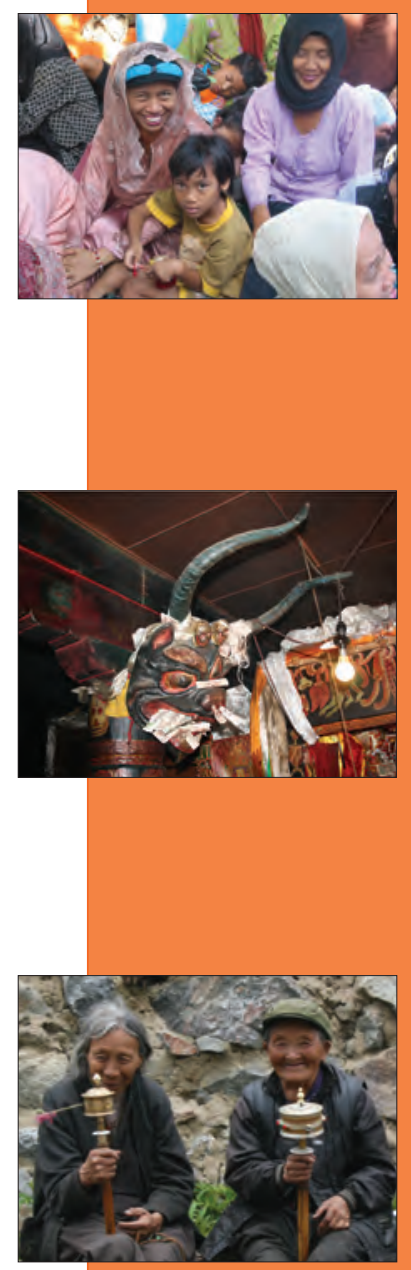

Band 6 


\section{AAS Working Papers in Social Anthropology / \\ ÖAW Arbeitspapiere zur Sozialanthropologie}

ISSN: 1998-507X

doi: 10.1553/wpsa6

ISBN: 978-3-7001-6656-6

Wien 2009

\section{Editors / Herausgeber:}

Andre Gingrich \& Guntram Hazod

(C) Forschungsstelle Sozialanthropologie

Zentrum Asienwissenschaften und Sozialanthropologie

Österreichische Akademie der Wissenschaften

Prinz-Eugen-Straße 8-10

A-1040 Wien

Fax: 01/ 51581-6450

E-Mail: sozialanthropologie@oeaw.ac.at 


\title{
THE (UN)MAKING OF POLICY IN THE SHADOW OF THE WORLD BANK:
}

\author{
Infrastructure development, urban resettlement \\ and the cunning state in India*
}

Shalini Randeria and Ciara Grunder

\begin{abstract}
"The government agreed to the World Bank policy, it was worked out together. Why does the government not keep to the policy? We don't want much; we simply want our problems solved according to World Bank policy. We are prepared to resettle but following World Bank policy....We are fighting because our project is a World Bank project."

Interview with Mr. Vasi, a displaced resident of Gazi Nagar (Mumbai) who filed a complaint before the Inspection Panel of the World Bank in 2004

"The World Bank should make reasonable demands. The government of Maharashtra was forced to accept the policy. But it was not possible for us to implement it. Conditions should be set, which can also be met. The World Bank should also respect property rights. Those affected by the project have no licences (for business) and no legal titles (to land)."

Interview with Mr. Datar (Secretary Special Projects, Government of Maharashtra)
\end{abstract}

The juridification of ever more domains of our lives today increasingly blurs the distinction between law in the strict sense of the term (i.e. rules enacted by a body with legitimate authority) and policy. Juridification denotes the creation and interpretation of rules, regulations and new soft law instruments by a range of actors - public and private, national and international. Policies and procedures of international financial institutions, development agencies and humanitarian organisations belong to an ill-defined domain at the intersection of international private law, public international law, technical norms and soft law. These policies lack legislative basis but acquire nonetheless law-like qualities and produce effects similar to the workings of law in the everyday life of individuals and communities in the South. This new architecture of governance has important implications for sovereignty and citizenship rights. Its study calls for a closer dialogue between fields that have hitherto developed relatively independently of one another: the anthropologies of law, development and policy.

The proliferation of juridification is also accompanied by the institutionalisation of new quasijudicial arena of mediation, arbitration and inspection at various scales. One consequence of this development is an increasing judicialisation of politics, or "lawfare" to use Jean and John Comaroff's term (2006). We argue that the expansion of legal forums, and their increased use by citizens to influence policy outcomes, neither necessarily strengthens the rights of citizens nor furthers the accountability of public institutions. Paradoxically, the spread of quasi-judicial bodies

\footnotetext{
* The present contribution is based on a paper presented by S. Randeria at the Social Anthropology Research Unit of the Austrian Academy of Sciences, April 18, 2008.

${ }^{1}$ Direct quotations and paraphrases of views expressed by actors derive from interviews carried out by Ciara Grunder during her fieldwork on the MUTP project in Mumbai from September 2006 to March 2007 (Grunder 2008). Names of interview partners have been altered to preserve anonymity.
} 
can create greater legal uncertainty for citizens, who are forced to navigate a maze of unfamiliar institutions with unclear, overlapping jurisdiction. States and international institutions are often able to render themselves unanswerable by passing the responsibility for policy design and execution to one another, or on to non-state actors involved in the process of its implementation. Ethnographic enquiry can fruitfully examine the effects and experiences of juridification, its ambiguities and limits, from the vantage point of actors in locations constituted as "local". Moreover, it can trace how the relationships between the national and international, internal and external or public and private are reconfigured through the transnationalisation of soft law and public policy. Analyses of the making and unravelling of policy call for sensitivity to its diachronic dimension too. For only a study of the worlds of policy over time can map "deformations of the planned and the formation of the unintended", as Sally Falk Moore (2005: 3) has pointed out.

Our ethnography explores some paradoxical outcomes of current processes of juridification that seek to regulate forced displacement in a World Bank funded infrastructure development project in Mumbai (formerly Bombay). It delineates the dynamics of the direct involvement of the international financial institution in the formulation of resettlement policy within the ongoing Mumbai Urban Transport Project (MUTP). The making and unmaking of this policy highlights the interplay between four actors (the World Bank, the MUTP project authority/ the Maharashtra government, NGOs and private firms of real estate developers). Yet neither the joint formulation of policy by the World Bank and the regional government nor its execution by NGOs and the private sector contribute to "good governance". On the contrary, a proliferation of policy actors leads to a dispersal of power and dilution of accountability. Those adversely affected by the project seek in vain to hold the state and World Bank accountable for problems of resettlement.

The chapter analyses the strategies of the World Bank and the state government, as they act against one another or in tandem, to disavow responsibility for the policy jointly negotiated between them. The World Bank takes credit for an innovative policy design but disclaims responsibility for implementation. Government officials in turn claim inability to put into practice an untenable policy, which there was no choice but to accept. Our case study aims to capture the politics of mutual complicity between World Bank and the borrower, on the one hand, and the politics of sovereignty used by the cunning state to render itself unaccountable to citizens and to international institutions alike, on the other. We use the notion of the cunning state (Randeria 2003, 2007a) to focus on the strategies of the state rather than its presumed (in)capacities. We argue against the view of subordinate states in the international system as merely weak either in terms of capacity to govern populations or territory or in terms of capacity to negotiate with powerful international financial institutions. Instead we seek to capture the constrained agency of states in the South in order to understand how it is used to legitimate certain policy options and outcomes. The idea of a cunning state is thus a useful way to delineate a range of tactics deployed at sites of negotiation where the state appears only to disappear and where it constructs and dismantles itself ways that renders it unanswerable.

Despite sustained demands from social movements and NGOs over the past three decades, the Indian state has yet to formulate a national resettlement policy. It has a dismal record of the expropriation of the poor having displaced some 500,000 people every year throughout the country since independence. Most of the over 30 million people forcibly evicted have neither received compensation nor been adequately resettled. The courts have been less than sympathetic to their grievances. The involvement of the World Bank in the MUTP introduces fairer standards 
of resettlement by way of credit conditionality into the national arena. Yet citizens are unable to influence through elected representatives the course and content of policy negotiations between the World Bank and the administration. Disaffected citizens try therefore to secure their rights to information, consultation, participation, resettlement and compensation using legal remedies within a labyrinth of administrative, judicial and new quasi-judicial institutions at various scales. We map this shift in the exercise of citizenship rights (i.e. from political participation to inspection and surveillance), which accompanies the transnationalisation of policy formulation. The chapter analyses the ambiguities of this process as experienced by two sets of actors in highly asymmetrical positions: officials of the regional government responsible for the implementation of MUTP and a group of persons displaced by the project. We discuss, on the one hand, the complex process of negotiation of resettlement policy between the World Bank and bureaucrats of the Maharashtra government and trace, on the other hand, the tenacious use of the Bombay High Court and the inspection mechanism at the World Bank by citizens protesting against violations of the policy.

\section{The Mumbai Urban Transport Project}

With a population of some 18 million people Mumbai, the capital of the province of Maharashtra and the commercial and finance metropole of India, is one of the largest cities in the world. The Mumbai Urban Transport Project (MUTP) aims to improve the inadequate transport infrastructure in this mega-city in order to further the mobility of people and goods. The World Bank views inadequate transport as a bottleneck for the economic development of the city and especially as a constraint for the poor, who need much longer travelling time to work (World Bank 2002: 6). The project consists of three components: the extension of the suburban railways network, the expansion of highways within the city and a programme of resettlement and rehabilitation for those displaced as a result. Of the estimated total cost of 945 million US dollars the World Bank has lent more than half (542 million US dollars). The rest comes from the Indian Railways, the federal and the regional governments (World Bank 2004a, 2004b).

The project loan includes a big budget for the resettlement and rehabilitation of some 120,000 people, whose homes, shops, businesses and small industrial establishments are situated on land needed for the enlargement of the city's transport infrastructure (World Bank 2002, 2004a and 2004b). ${ }^{2}$ The massive scale of urban resettlement is unprecedented for a World Bank funded project anywhere in the world except China. The inclusion of a resettlement policy into the project design and a large loan for the purpose are exceptional too. In fact, MUTP is unique in being the first infrastructure project financed by the World Bank that includes a budget for resettlement. Yet issues of resettlement and rehabilitation have turned out to be the Achilles heel of the project. No other project funded by World Bank has led to so many complaints about trenchant violations of the institution's own safeguard policies to be filed before its Inspection Panel, a quasi-judicial body. The report of the latter led the World Bank management in 2006, for the very first time, to temporarily suspend credit for a project in India. The reaction of the project authorities was as revealing as the subsequent actions of the lending institution. The former publicly welcomed the

${ }^{2}$ This final figure has had to be continually revised upward over the years pushing up project costs and complicating the implementation of the plans for rehabilitation. See the Resettlement and Rehabilitation Policy for MUTP, March 1997 (amended 2000) for the broad definition of "Project Affected Persons" adopted at the behest of the World Bank. 
withdrawal of the imperious institution, which had infringed on national sovereignty and imposed impracticable conditions. The latter soon resumed the credit despite the absence of significant improvement in the condition of the displaced families. It is this dance of donors with dependent states, to use Sally Falk Moore's evocative expression (2002), and its consequences for affected citizens, that our ethnography details.

Planning for the gigantic project to improve the suburban railway infrastructure began in 1995. The project was represented as pivotal to economic growth, improvement of the quality of life and poverty reduction in the city. But a second component, namely the extension of highways, was added to the original plan shortly before the loan document was finalised in 2002. By then the resettlement policy for the project had already been drafted with a view to the needs of those families, whose homes along the railway tracks were to be demolished. The belated inclusion of the extension of highways along the Santa Cruz-Chembur Link Road and the Jogeshwari-Vikroli Link Road into the MUTP created several problems. The costs for the resettlement of those displaced by the road expansion had not been adequately budgeted for in the loan agreement. Moreover, those displaced due to the new highways included owners of shops, businesses and small industrial units, whose rehabilitation needs were different too. It is this group that has been at the forefront of legal action against violations of MUTP resettlement policy. The Regional Safeguards Advisor of the World Bank felt that the inability to design differential compensation packages for various groups of displaced persons was an important factor in precipitating the conflict around resettlement.

However, officials of the government of Maharashtra took a different view. They pointed out that it was not the application of the policy to an additional set of persons that was problematic but the basic premises of the resettlement policy itself were flawed. In their view government was being forced to violate its own laws on land acquisition and its policy on slum clearance in order to comply with the World Bank's unreasonable demands on the question of resettlement. During the policy negotiations officials were opposed to the acceptance of resettlement norms at variance with the country's laws and policies, which provided no compensation for those without legal titles to land acquired by the state for a public purpose. Partial and selective implementation of the policy was therefore justified by bureaucrats with reference to its utter unsuitability for the local context and its disregard for national policy, as the quotation from an interview with a senior bureaucrat at the beginning of the chapter illustrates.

\section{Negotiations on resettlement policy}

The World Bank, wary of repeating its earlier mistake in seriously underestimating the nature, extent, cost and massive problems of displacement caused by the dams on the river Narmada that it had financed in part, insisted on incorporating a resettlement policy within the MUTP from the start. In the late 1980s and early 1990s a transnational advocacy network had mobilised public opinion worldwide against the Sardar Sarovar dam that caused the forcible displacement of nearly 200,000 people without adequate compensation measures (Randeria 2003). The successful campaign led the government of India to forego the remaining credit for the Narmada project. This terminated the involvement of the World Bank in probably the most controversial infrastructure project in its entire history. The campaign also brought about significant policy changes at the World Bank including the formulation of its current policy on involuntary displacement (Fox and Brown 1998). 
The World Bank's Operational Policy (OP)/Bank Procedure (BP) 4.12 (Policy on Involuntary Resettlement) is binding on all borrowers for projects involving displacement (World Bank n.d.). ${ }^{3}$ The safeguard policy enjoins prior consultation with those to be displaced in order to ensure their participation in the planning and implementation of resettlement programmes. These programmes are to be executed with a view to sustainable development that enables those affected by a project to share in its benefits. The policy also aims to assist those to be displaced 'to improve their livelihoods and standards of living or at least to restore them, in real terms, to pre-displacement levels or to levels prevailing prior to the beginning of project implementation, whichever is higher'. Many of these norms, which were incorporated into MUTP resettlement policy, originally stem from demands advocated by environmental NGOs in the North and social movements in the South in the course of the campaign against the Narmada dam. Understanding paths and patterns of diffusion and domestication of policy in various locations thus calls for a study of connections across sites and scales as well as over time. What appeared to Maharashtra government officials to be unfeasible policies imposed by the World Bank top down turn out on closer examination to incorporate norms originating from civil society actors including some from India. These norms are subsequently diffused to borrowers in the South through their incorporation into the operational policies of the World Bank. Such circuitous policy making increasingly blurs the boundaries between actors within and beyond the nation-state.

A close reading of the documents on the MUTP project, supplemented by interviews with some of the Indian bureaucrats involved in the negotiations, reveals the process by which policy prescriptions of the World Bank were turned into policies of the government of Maharashtra. As the World Bank, for example, notes in its Project Appraisal Document, “... GoM (Government of Maharashtra) had issued a Government Resolution (GR) adopting the policy in March, 1997 which was later amended in line with the Bank's OD (Operational Directive) 4.30 on involuntary resettlement. The modified version was reviewed and endorsed by the World Bank in February, 2000. Subsequently, the GoM (Government of Maharashtra) has brought out a Government Resolution (Prakalpa 1700/CR 31/Slum 2, dated December 12, 2000) signifying the adoption of the revised policy for the project." (World Bank 2002: 98, information on abbreviations in parentheses added by the authors). Interventions in the formulation of policy by donors are thus represented and justified as the consent of the recipient state (Anders 2008). Or as Sally Falk Moore (2002) has put it, the command of aid conditionalities is couched in the language of contract. Such a 'construct of presumed consent' (Mattei 2003: 385) inverts accountability by shifting responsibility for the implementation of the World Bank's operational policies (OP) and directives (OD) onto an often unwilling borrower with no choice but to accept the terms of a loan agreement. But the cunning state can use its latitude in the interpretation and execution of policy to undermine the agreed upon policy. It is able to get away with even gross infringement of policy with impunity by raising the sensitive issue of violation of national sovereignty by the World Bank.

The incorporation of the World Bank's operational policy norms into the resettlement policy of MUTP was a matter of protracted negotiation with the government of Maharashtra. The latter instituted a working group on resettlement policy comprising of senior government officials and the private sector to iron out differences behind closed doors. Sundar Burra, adviser to SPARC, a NGO entrusted with implementing MUTP resettlement programmes, notes that "The

${ }^{3}$ OP/BP 4.12 together have replaced the earlier Operational Directive (OD) 4.30 on Involuntary Displacement. 
World Bank required that there be civil society representation on the Task Force to formulate R\&R (resettlement and rehabilitation) policy" (Burra 2001: 5). The task force, which included representatives of NGOs, recommended that each family to be evicted be given $225 \mathrm{sq}$. ft. (or 20,91 sq.m.) of accommodation free of cost. Government officials gave in to the World Bank's demand to provide alternative housing to those evicted but insisted on limiting its size. But they refused to acquiesce to the World Bank directive to compensate for loss of income or restoration of the existing standard of living. Moreover, officials warned against setting a precedent within MUTP, which they would be hard put to replicate elsewhere. As Mr. Datar, a senior bureaucrat in charge of infrastructure projects put it, "We (the government of Maharashtra) have nine such projects, the World Bank only one. It is impossible to implement the other projects according to the same resettlement standards as the World Bank one. The state simply does not have the funds for this." However, affirmations of state incapacity by government officials must be seen as strategic. Bureaucrats reacted in press interviews to the temporary suspension of the World Bank credit due to gross violations of the resettlement policy, for instance, by stressing the ability of the state to implement the project without the pressure of World Bank aid with strings. They faulted the rigorous MUTP resettlement policy for having slowed down progress on the project, and increased costs, and thus ultimately to the inability of the project authorities to meet the demands of the World Bank for speedy implementation and a positive cost-benefit ratio.

MUTP resettlement policy grants far more rights to persons forcibly displaced by the project than any other policy for expropriation of land for public purpose or slum demolition followed in India so far. ${ }^{4}$ Small wonder that those adversely affected by the project are adamant that World Bank policy (and not national law) apply to them, as Mr. Vasi insists in the interview from which we quote at the beginning of the chapter. Policies tied to development projects, however, raise vexed issues of legal pluralism and the fragmentation of citizenship rights. World Bank structural adjustment policies, for example, affect all citizens even if their impact is far from uniform within the borrowing country. Policies framed within a particular development intervention, however, carve up state territory into project areas and populations to whom norms negotiated with a particular international organisation apply. These norms may differ with the donor in question and may also be at variance with national laws and policies. People displaced by infrastructure development projects in Mumbai are, for example, divided into those affected by MUTP and those displaced by projects without World Bank funding. Only the former are eligible to stake claims for compensation according to World Bank norms as incorporated into MUTP policy.

The existence of dual standards caused dissatisfaction among those displaced due to different infrastructure development projects in the city. The plurality of resettlement norms was also partly responsible for considerable confusion in identifying beneficiaries as claimants swelled the ranks of those eligible for compensation under MUTP. Government officials sought to reclassify the homes and shops of many of these protestors as falling under the plans for eviction as part of the Mithi river project, one without World Bank involvement. The policy framed within the MUTP is limited to the duration of the project. Yet the World Bank entertained the vain hoped that it would form the proto-type of future regional and national policy. Officials of the Maharashtra government, however, stated in no uncertain terms that it would not be extended beyond the ambit of MUTP.

\footnotetext{
${ }^{4}$ Activists of the National Working Group on Displacement have advocated norms for fair resettlement and
} rehabilitation that go much beyond those adopted by the World Bank (Randeria 2003, 2007a). 
The World Bank policy on Involuntary Resettlement, which enjoins compensation regardless of the duration of residence prior to eviction or possession of legal titles to property, contravenes earlier policies of the government of Maharashtra too. Although the Maharashtra government was averse to keeping its own policy temporarily in abeyance for households dislocated due to the MUTP, it was forced to accede to the demands of the World Bank management. Almost all those displaced by the MUTP belong to the official category of "slum-dwellers" without legal title to their homes or business property (World Bank 2004a: 5). This is not surprising as more than half of the population of Mumbai inhabits so-called "slums" (MTSU 2006) built on either private or public land. Government officials objected strongly to the demand of the World Bank for rehabilitation of those who in the eyes of the law are "illegal encroachers". Officials went so far as to append a note of dissent to the MUTP policy stating that the World Bank's insistence to compensate illegal "slumdwellers" sets a dangerous precedent that encourages lawlessness and rewards illegal occupation of land. The fact that MUTP policy was at odds with the international financial institution's insistence on respect for property rights did not escape notice either, as exemplified by the quotation from an interview with a senior bureaucrat at the beginning of the chapter.

\section{Non-state actors of policy implementation: real estate developers and NGOs}

During the protracted negotiations on the project, Maharashtra government officials had strongly opposed the World Bank's initial suggestion that the responsibility for the resettlement programme be fully given over to a private corporation. They had advocated instead the choice of MMRDA (Mumbai Metropolitan Regional Development Authority). Yet neither the MMRDA, nor even the World Bank for that matter, had any experience with urban resettlement on such a large scale, as Mr. Nayar, the former chief of Resettlement and Rehabilitation at MUTP conceded. The World Bank solved this problem by redefining it as one of the weakness of urban governance institutions in India, which suffered from a fragmentation of functions and responsibilities as well as from lack of overall coordination. The Project Appraisal Document for MUTP therefore proposed to reform the MMRDA into an efficient and transparent organisation according to the "good governance" criteria of the international financial organisation (World Bank 2002: 37).

Interestingly, there was no disagreement between the World Bank and the Maharashtra government about the involvement of private real estate developers, a component of MUTP resettlement policy that was imported from the Slum Rehabilitation Scheme in the city. Private firms were selected to build the new apartment blocks for resettlement. In exchange for the construction of these buildings they were given permission to develop property in prime areas of Mumbai. World Bank documents are full of praise for this "innovative" market-oriented approach using so-called Transferable Development Rights (TDR) (World Bank 2004b: 7-8 and 2006: 44), which enabled the state to acquire additional private land for purposes of infrastructure development (World Bank 2002: 99). TDR gives the developer the right to build at another location, or to sell to a third party the right to build, 2,5 times the floor space index (FSI) generated for resettlement. In return for providing 1000 sq.m. of built space to house those affected by the MUTP, for example, a firm of developers acquires the right to construct commercial or residential space of 2500 sq.m. elsewhere in the city. Noting the extremely poor quality of the new buildings for displaced families Mr. Wadoo, an activist of the Bombay Environmental Action Group remarked, "Instead of the earlier horizontal slums now vertical ones have been built and that too on a much smaller area of land than earlier. 
Those who have profited are the builders thanks to the TDR." The choice of new locations for resettlement at the outskirts of the city reflected the interests of powerful firms of developers and not the preferences of the displaced for accommodation close to their original homes and business premises. The latter had not been consulted prior to relocation in violation of the World Bank's policy, as the Inspection Panel found upon its investigations into complaints.

The involvement of non-state actors to implement resettlement policy reflects the World Bank's neo-liberal prescriptions for development. But it may also be seen as a reaction to the Indian state's recalcitrant attitude towards questions of forced displacement in the past. Having learnt its lesson from the controversial Narmada dam project, the World Bank insisted on entrusting responsibility for MUTP resettlement programmes to NGOs with high local legitimacy. The NGOs contracted for the purpose were: SPARC (Society for the Promotion of Area Resource Centres), SRS (Slum Rehabilitation Society) and NSDF (National Slum-Dwellers Federation), which includes the Railway Slum Dwellers Federation that represents the interests of families living along the railway tracks in Mumbai. All three organisations have a long record of active involvement in furthering the right to housing for the urban poor. They have furthered dialogue between slum-dwellers and the state to solve problems arising from lack of civic amenities, evictions and relocation. The NGOs see themselves as facilitators, who enable local communities to organise themselves through participatory processes (SPARC/NSDF n.d.; SRS n.d.). Whereas SPARC represents itself as "one David against three Goliaths (the World Bank, Indian Railways and the government of Maharashtra) (Patel and Sharma 1998), for those protesting inadequate resettlement the battle lines were drawn differently.

The NGOs were contracted to carry out baseline socio-economic surveys of the households to be dislocated, to draw up resettlement plans and implement them. The MUTP project authorities had to be pressurised by the World Bank into giving up responsibility for the implementation of these parts of the project. Thus the NGOs took over the burden of determining eligibility for compensation and issuing identity documents in the absence of any existing system of identity cards or registration of residence by the state. Among the contentious issues, which were left to the NGOs to resolve were: who constituted a family, which kin and affines could be counted as belonging to a household, whether they had to be resident in the structure to be demolished at the time of relocation, whether those currently absent from Mumbai in the village could be counted as family members, and who should bear the cost of their travel to the city to be photographed for purposes of identification and compensation. Moreover, SPARC and NSDF were also given a contract to construct the 2500 flats necessary to temporarily house those who had to be urgently relocated before the flats at the resettlement site had been built. The NGOs offered to construct these "transit tenements at about $75 \%$ of the estimated cost, making the offer attractive both to the (World) Bank and the MMRDA (Mumbai Metropolitan regional Development Authority in charge of project implementation)..." (Burra 2001: 6).

The responsibility for the identification and resettlement of nearly 120,000 persons thus rested with NGOs, who also bore the brunt of the criticism that was deflected away from the World Bank and the state government or MMRDA, the nodal agency that coordinates the project. Policy outcomes vary with the local constellation of actors, who implement and contest it on the ground. The involvement of the World Bank alters the dynamics of such conflicts for it introduces a powerful actor with norms and institutional mechanisms, which can be used by activists to set aside national 
laws and policies (Randeria 2003, 2007b). Disaffected citizens in the MUTP case simultaneously filed a petition before the Bombay High Court and requested the Inspection Panel of the World Bank to enquire into breach of resettlement policy.

\section{The futile search for quasi-judicial remedies: inspection mechanisms at various scales}

Established in 1993, the Inspection Panel is by no means a full-fledged body for adjudication but provides a forum for a complaint by any party adversely affected by a World Bank funded project. The independent body represents an innovation in international law, whereby individual citizens are for the first time formally allowed access to an international financial organisation. Its establishment responds to a long-standing demand by civil society actors, which was also voiced forcefully by the transnational coalition against the Narmada dam. They demanded the accountability of the World Bank not only to its member states but equally to citizens in debtor countries, who, though affected by its lending policies, have no voice in its functioning. Although the (in)action of borrower governments is beyond the purview of the Inspection Panel, it has been used not only to ensure compliance with World Bank safeguards policies but primarily to pressurize one's own government to adhere to World Bank's norms or standards (Clark et al. 2003; Randeria 2003, 2007). The primary purpose of the Inspection Panel, a three-member body with investigatory and advisory powers, is to examine compliance by World Bank staff with the safeguard policies and procedures laid down by the institution that are also binding on the borrower. Its establishment does not render the World Bank legally liable, nor does it provide for compensation even to those whose complaints are found to be justified. In using it as a forum to seek remedy, citizens and civil society organisations also challenge the nation-state's exclusive claim to speak for its citizens and represent their interests at the international level.

In 2004 and 2005 four requests for investigation into infringements of MUTP resettlement policy were made to the Inspection Panel. Complaints concerned the lack of consultation with the community, the choice of inappropriate relocation sites and inadequate restoration of incomes and living standards due to the unavailability of access to essential services such as schools, medical services, water and waste removal facilities. It was contended that relocation in far away areas inaccessible by public transport had led to severe problems of mobility, an increase in travel expenses and commuting time to work and to a loss of daily wages for poor households, who could least afford such costs. Adequate rehabilitation according to World Bank policies must therefore compensate for disruption of livelihood and a decline in standards of living, petitioners claimed.

But as the conflict between the MMRDA, the project implementing authority and those who filed a request for inspection made clear, the cunning state had little intention of abiding by the policy negotiated with the World Bank. The petitioners drew attention to the callousness and the highhandedness of MMRDA officials, who had consistently failed to address their concerns. In a letter to the Inspection Panel, the representatives of the families to be displaced from Gazi Nagar recorded their altercation with the then head of the project implementation authority, as follows: "Mr. T. Chandrashekhar proudly replied us that this is India and not America. One cannot hold us that much accountable and responsible as Americans are! When we told him that it means you people are not as accountable and responsible as expected by the World Bank, Mr. T. Chandrashekhar replied in yes (sic) and further stated that the people of Gazi Nagar should not expect any such 
accountabilities and transparencies from him nor from the government [sic]. . Now we the poor residents of Gazi Nagar are unable to understand where to go for justice in such circumstances" (World Bank Inspection Panel 2004: 47).

Residents of Gazi Nagar recalled that members of the Inspection Panel had explained to them during the site visit to Mumbai that it could merely document violations of policy but had no powers to take decisions to improve implementation. In its view the power to improve the situation of the displaced lay with the World Bank management. Once management responds to the report of the Inspection Panel by putting before the Executive Directors of the World Bank an "action plan" for improvement in the implantation of the project, which it devises together with the borrower, neither the complainants nor the Inspection Panel have the right to comment on the plans further (Clarke et al. 2003: 267). Besides formulating such a plan jointly with the MMRDA, the World Bank management also reacted to the numerous complaints to the Inspection Panel by prevailing on the project authorities to activate the grievance redress mechanisms established within MUTP.

The case before the Bombay High Court and the complaint to the Inspection Panel compelled MMRDA to take steps towards the formalisation of the functioning of these grievance instances. But even in 2006 no regular hearings took place and complaints to the Field Level and Senior Level Grievance Redress Committees responsible for assessing the eligibility for compensation were summarily dismissed. Indignant at being forced to institute complaints mechanisms within MUTP at the behest of the World Bank, and distrustful of the urban poor, bureaucrats saw to it that the new instances remained totally ineffective. Following criticism by the Inspection Panel, the Independent Monitoring Panel (IMP) within MUTP, a third body instituted under pressure from the World Bank, was broadened to include independent members from outside the state bureaucracy. But in the absence of any competence to take binding decisions, the IMP too remained ineffective. Nevertheless Mr. Parasuraman, chief of resettlement and rehabilitation at MUTP and Mr. Sonowal, director of MUTP were impatient with all the discussions within IMP. The latter felt that, "In projects one must bridge the gap between two aims: follow procedures and realise project aims. If one always only focuses on procedures, then no progress is possible."

Not surprisingly, these non-functioning quasi-judicial instances brought no relief to those who had lost homes and businesses. But their existence on paper relieved the World Bank of its responsibility to address problems of implementation. It also deflected demands for accountability addressed to the World Bank management onto the project authorities, who in turn pointed to the existence of the three tier grievance redress mechanism within MUTP in order to demonstrate compliance with credit conditionality in the area of "good governance". Citizens remain sceptical of these internal mechanisms. As Mr. Shaban, a member of the United Shop Owners Association that filed a request to the Inspection Panel, remarked, "What kind of a bureaucracy is this, which is defendant, judge and lawyer in one? How can one expect justice here?" Moreover, these various MUTP bodies do not seem to have any legal status or established procedures. Their main function seems to be to prevent complaints to, and further investigations by, the Inspection Panel of the World Bank, an aim that both borrower and lender were interested to achieve.

Matters came to a head, however, as MMRDA, the project implementing authority, seemed to be unable or unwilling to resolve the serious problems of resettlement. Following a spate of complaints, the Inspection Panel went ahead with a limited field investigation into allegations of 
policy violations. Its highly critical report detailed infringement of the policy on environmental assessment, on project supervision and on involuntary displacement. It was critical of the choice of resettlement sites, the overestimation by the World Bank management of the capacities of the NGOs and the project authority to carry out resettlement programmes on such a large scale, the ineffectiveness of the grievance redress mechanisms within MUTP and deterioration in living standards after relocation (World Bank IP 2005 and 2006). The report forced the World Bank to temporarily suspend the disbursement of the remaining 20 percent of the IDA credit and the 150 million US dollar loan for the controversial road and resettlement components of the project in March 2006. The cunning state, however, welcomed the suspension as a blessing in disguise, as it afforded an opportunity to sidestep the stringent standards of the World Bank. The then head of MMRDA, Mr. Chandrasekhar, stated in an interview to the press that it would be cheaper, quicker and less cumbersome to implement the project without World Bank policies and standards, which push up the costs of resettlement and rehabilitation to a level that was not feasible for the project authority to meet. According to him, "The World Bank has a lot of harsh impractical conditions. They want us to use global laws for local conditions" (Deshmukh and Mehta 2006). He announced that MMRDA would consider turning to Japanese banks to complete the project, which lent funds at lower rates without social and environmental conditions attached to them. This turned out to be an empty threat. The federal government prevailed on the project authority and the Maharashtra government not to exacerbate the conflict so as not to jeopardise relations with the World Bank.

\section{Exercise of citizenship rights through legal action}

Defining democracy as the 'politics of the governed' (2004: 4), Partha Chatterjee points to the emergence of a new distinction between citizens and populations in contemporary regimes of power, following Foucault's idea of the 'governmentalization of the state'. He argues that these regimes do not secure legitimacy through the political participation of citizens. Instead, their legitimacy rests on claims to provide for the well-being of statistically defined populations as the objects of social and economic policies. Policy thus comes to replace politics, just as the rule of experts substitutes for political representation. Whereas the right to vote in a representative democracy still remains tied to a world of territorial nation-states, the right to inspect and to judge, the right to evaluate or denounce have not merely gained significance but are also being exercised both within and beyond state boundaries, as our case study shows. Although those at the margins of the nation-state may have recourse to new transnational arena like the Inspection Panel of the World Bank this does not mean that they live in a world of "post-national" or "pluri-national" citizenship, which is a privilege reserved for another class of citizens. Pierre Rosanvallon (2006) has identified the tendency towards increasing surveillance and control as a central aspect of what he calls 'counter-democracy' at the national level. But even at the transnational scale it is easier for citizens to inspect or name and shame governments than it is to improve access to, and gain representation in, international institutions.

One aspect of this shift is the increasing use of courts at all levels by citizens rather than participation in elections to render governments accountable. Political mobilization, parliamentary debates and street demonstrations are conspicuous by their absence in the Mumbai case. These have been increasingly displaced onto litigation in the High Court and the international arena. The MUTP case is remarkable for the tenacity with which those seeking adequate rehabilitation have focussed almost 
exclusively on the search for legal remedies. However, claims in the judicial or quasi-judicial arena also require extensive prior mobilisation on the ground. Their outcome in these arenas may also depend to a considerable extent on the success in marshalling resources, capturing media attention and sustaining political pressure. The media (especially the English language press in Mumbai) has been rather hostile to the rights of slum and pavement dwellers in the city. The middle classes consider them to be lawbreakers, who illegally occupy valuable public or private land and create a public nuisance. There has been a sustained campaign to "beautify Bombay" by summarily evicting those who disfigure the city by using public space for sleeping, cooking and defecating. The urban poor are represented as "free riders", who use amenities that middle class tax payers sustain.

Interestingly, in the early stages of MUTP a public interest litigation petition was filed by a NGO asking for the demolition of all slums along the railway tracks without compensation (Burra 2001). The High Court in all likelihood would have conceded the demand had it not been for the assurance of the government of Maharashtra that it would urgently implement a resettlement programme for the affected families. It is unlikely that the government would have taken this view if it had not known itself to be under scrutiny from the World Bank in this regard. However, the petition by those seeking to avert eviction due to the extension of highways under MUTP was turned down by the Bombay High Court. ${ }^{5}$ They were asked to present their problems to the internal grievance redress mechanism within the MUTP as requested by the defendants, the project authorities. But the court also ruled that no evictions were to undertaken until rehabilitation according to the norms of the MUTP resettlement policy is provided. The court thus upheld World Bank policy rather than national law to be applicable in this case. Disregarding the court judgement and its own policy, MUTP went ahead with evictions and demolitions while complaints by residents were pending before a grievance committee. By filing a compliant to the Inspection Panel of the World Bank the petitioners could circumvent the administrative and judicial machinery of the state temporarily but they remain dependent on it in the long run. Disappointed by the lack of improvement in resettlement programmes despite the Inspection Panel having recorded serious violations of policy, citizens turned once again to the Bombay High Court to complain against corruption and mismanagement in MUTP. This case is still pending.

Efforts by citizens to organise and press claims in legal forums at the national or transnational scale are concerned with issues of inspection and judgement rather than with the core classical concerns of citizenship around questions of legitimacy, participation and representation. A broader grammar of governance has thus emerged, one that has extended the vocabulary of citizenship both within the nation-state and outside it. One of the dilemmas faced by citizens in the new architecture of non-accountability is to identify the addressee of protest. Activists differ in their assessment of the efficacy of using local, national or transnational arenas either exclusively, consecutively or simultaneously. The strategic choices they make also vary with the issue in question as well as their location and ideology. Moreover, the resources available to local actors vary and also determine the levels of support they can marshal at different scales, the networks they are able to tap into or the coalitions they can build and sustain. As the Mumbai case demonstrates, the addressee of the protest, the scale at which it is voiced and the strategy used to further claims can also shift in the course of a struggle.

\footnotetext{
${ }^{5}$ Activists of the National Working Group on Displacement have advocated norms for fair resettlement and rehabilitation that go much beyond those adopted by the World Bank (Randeria 2003, 2007a).
} 


\section{Conclusion}

Anthropology of policy provides a useful vantage point to map processes of the restructuring of state and its relationship with international financial institutions and citizens. It is well suited to capture shifts in rhetoric and practices of sovereignty as well as the exercise of citizenship rights. Our ethnography of the (un)making of resettlement policy within the MUTP has explored how soft law attains efficacy in everyday life in a particular place. An understanding of processes of juridification in a developmental state, aptly termed "a state of endemic expropriation" by Jean and John Comaroff (2006: 15), requires the study of dynamic and conflict-laden fields. The boundaries of these fields are not pre-given but are empirically determined in relation to our objects of enquiry. Processes of policy making can not be understood without reference to the workings of larger forces, which are global in reach but local in their manifestations.

We have shown that the same World Bank policy can produce very different outcomes in different contexts depending on the bargaining strength of the borrowing state and the extent to which it is able to circumvent policies negotiated under conditions of unequal power. Yet the state is neither a passive recipient of external policy prescriptions nor without means to affect their realisation in a local context. While it is an object of neo-liberal restructuring, the state actively shapes these policy outcomes too. We use the idea of the cunning state to counter discourses of state weakness that proliferate in academic and policy circles. The cunning state can successfully render itself unaccountable by legitimising its lack of political will to implement a policy in terms of its inability to do so. Partial compliance and foot-dragging can be interpreted in turn by the World Bank as the need to improve state capacities and governance. The dispersal of power in transnationalised worlds of policy leads to a loss of transparency in decision-making as well as to a dilution and divestment of responsibility. In such a context, the proliferation of processes of juridification, and the establishment of new quasi-judicial arena, has been experienced by various actors as simultaneously empowering and disempowering. Our ethnography has explored the equivocal nature of some of these developments that hold out a promise they have yet to fulfil.

Shalini Randeria is Professor of Social and Cultural Anthropology at the University of Zurich.

Ciara Grunder is an anthropologist who currently holds an assistant post at the University of Zurich. 


\section{References}

Anders, Gerhard. 2008. The Normativity of Numbers: World Bank and IMF Conditionality. PoLAR: Political and Legal Anthropology Review 31(2) (in press).

14 Burra, Sundar. 2001. Resettlement and Rehabilitation of the Urban Poor: The Mumbai Urban Transport Project. A Case Study. Online, www.sparcindia.org, retrieved 10.10.2007.

Chatterjee, Partha. 2004. The Politics of the Governed: Reflections on Popular Politics in Most of the World. New York: Columbia University Press.

Clarke, Dana, Fox, Jonathan and Treakle, Kay. 2003. Demanding Accountability: Civil Society Claims and the World Bank Inspection Panel. India: Rainbow Publishers Ltd.

Comaroff, Jean and Comaroff, John L. (eds.). 2006. Law and Disorder in the Postcolony. Chicago: University of Chicago Press.

Deshmukh, Smita/ Mehta, Rajshri. 2006 (March 3). World Bank stops aid, state not perturbed. DNA, Daily News \& Analysis. Online, www.dnaindia.com, retrieved 08.09.2006.

Fox, Jonathan and Brown, David L. 1998. The Struggle for Accountability: The World Bank, NGOs, and Grassroots Movements. Cambridge/Mass.: MIT Press.

Grunder, Ciara. 2008. Wer macht sich hier breit? Transformation in eine „Weltklasse-Stadt": Das ,Mumbai Urban Transport Project' und die Umsiedlung von SlumbewohnerInnen. Lizentiatsarbeit, Institute of Social Anthropology, University of Zurich.

Mattei, Ugo. 2003. A theory of imperial law: A study on U.S. hegemony and the Latin resistance. Indiana Journal of Global Legal Studies, 10(1), 383-449.

Moore, Sally Falk. 2002. An international regime and the context of conditionality. In: Likosky, Michael (ed.) Transational Legal Processes: Globalisation and Power Disparities. London/ Edinburgh: Butterworths and LexisNexis.

Moore, Sally Falk. 2005. Comparisons: Possible and Impossible. Annual Review of Anthropology 34, $1-11$.

MTSU, Mumbai Transformation Support Unit. 2006 (March). Strategy for Land and Housing Develop-ment, Mumbai: All India Institute of Local Self-Government.

Patel, Sheela and Sharma, Kalpana. 1998. One David and Three Goliaths. Mumbai Transport Case Study. Online, www.sparcindia.org, retrieved 15.10.2007.

Randeria, Shalini. 2003. Cunning States and Unaccountable International Institutions: Social Movements and the Rights of Local Communities to Common Property Resources. European Journal of Sociology 16(1), 27-60.

Randeria, Shalini. 2007a. Which State is Globalisation in? International Institutions, Social Movements and the Cunning State in India. Theory, Culture \& Society 24(1), 1-33.

Randeria, Shalini. 2007b. Global Designs and Local Lifeworlds: Colonial Legacies of Conservation, Disenfranchisement and Environmental Governance in Postcolonial India. Interventions: Journal of Postcolonial Studies 8 (1).

Resettlement and Rehabilitation Policy for Mumbai Urban Transport Project (MUTP). March 1997 (as amended in December 2000). Government of Maharashtra, Housing and Special Assistance Department, Mantralaya, Mumbai. 
Rosanvallon, Pierre. 2006. Democracy Past and Future. New York: Columbia University Press.

Slum Rehabilitation Society, NGO (n.d.) Portrait. Online, www.srscindia.org, retrieved 10.04.2008.

SPARC/NSDF, NGO (n.d.) Portrait. Online, www.sparcindia.org, retrieved 10.04.2008.

World Bank. 2002 (May). Project Appraisal Document. Mumbai Urban Transport Project. Online, www.worldbank.org, retrieved 10.09.2007.

World Bank. 2004a (May). Bank Management Response to Request for Inspection Panel Review of the India - Mumbai Urban Transport Project. Online, www.worldbank.org/inspectionpanel, retrieved 10.03.2005.

World Bank. 2004b (July). Bank Management Response to Request for Inspection Panel Review of the India - Mumbai Urban Transport Project. Online, www.worldbank.org/inspectionpanel, retrieved 10.03.2005.

World Bank. 2006. Management Report and Recommendation in Response to the Inspection Panel Investigation Report. India Mumbai Urban Transport Project. Online, www.worldbank.org/ inspectionpanel, retrieved 12.10.2007.

World Bank (n.d.) Policies and Procedures. Online, www.worldbank.org, retrieved 03.09.2008.

World Bank Inspection Panel. 2004. Bank management's response to request for Inspection Panel review of the India-Mumbai Urban Transport Project (IBRD loan No. 4665-IN, IDAcreditNo.3662IN), http://siteresources.worldbank.org, retrieved 12.7.2005.

World Bank Inspection Panel. 2005. The Inspection Panel Investigation Report. Online, http:// siteresources.worldbank.org, retrieved 10.10.2005.

World Bank Inspection Panel. 2006. The Inspection Panel Annual Report 2005-06. Online, http:// siteresources.worldbank.org, retrieved 15.8.2007. 